\title{
Resume Sistem Ekonomi Kapitalisme
}

\author{
Mega Lestari (90100118011)
}

Kapitalisme berasal dari kata capital yakni modal, yang diartikan sebagai alat produksi seperti tanah dan uang. Sedangkan kata isme sendiri berarti paham atau ajaran. Sehingga kapitalisme dapat diartikan sebagai sistem ekonomi politik yang cenderung ke arah pengumpulan kekayaan secara individu tanpa gangguan dari kerajaan atau campur tangan pemerintah. Pengertian lainnya menurut Ayn Rand, mengatakan bahwa kapitalisme adalah a social based on the recognation of individual rights, including property rights, in which all property is privetely owned. Kapitalisme ini diperkenalkan oleh tokoh ekonomi berama Karl Marx, yang memaknai kapitalisme sebagai pemilik modal (kapital) memiliki hak penuh terhadap apa yang dimiliki (Huda 2016).

Menurut Dudley Dillard, sejarah kapitalisme melewati tiga tahapan fase, yaitu kapitalisme awal, kapitalisme klasik, dan kapitalisme lanjut.

\section{Kapitalisme Awal (1500-1750)}

Dimulai dari lahirnya institusi pasar (market) pada abad ke-16 dan kemudian dilanjutkan dengan perkembangan perdagangan jarak jauh antar pusat-pusat kapitalisme dunia. Dalam ekonomi kapitalis, pasar memiliki peran penting dalam sistem perekonomian dimana pasar bebas untuk menyelesaikan permasalahan mulai dari produksi, konsumsi, dan distribusi (Parakkasi dan Kamiruddin 2018). Kapitalisme awal ini dibuktikan dengan kehadiran pabrikasi sandang di Inggris yang menjadi industri terbesar di Eropa. Industri inilah yang kemudian menjadi pelopor lahirnya kapitalisme. Dari beberapa kejadian dan faktor lingkungan yang mempengaruhi pembentukan modal di awal kelahiran kapitalisme ini, yaitu: 1) dukungan agama bagi kerja keras dan sikap hemat; 2) pengaruh logam-logam mulai dari dunia baru terhadap pekrkembangan relatif pendapatan atas upah, laba, dan sewa; 3) peranan negara dalam membantu dan secara langsung melakukan pembentukan modal dalam bentuk bendabenda modal aneka guna (Huda 2016).

\section{Kapitalisme Klasik (1750-1914)}

Pada fase ini, kapitalisme mengalami perubahan yang pada awalnya dari monopoli kapital kemudian menjadi kapital industri. Perubahan ini adalah ciri dari revolusi industri di Inggris. Sehingga, penerapan ilmu pengetahuan teknis yang ada selama berabad-abad lamanya, lambat laun berubah. Dengan demikian, kapitalisme berubah menjadi pelopor bagi perubahan teknologi karena akumulasi pembaharuan. Pada masa ini pula, kapitalisme memulai dan meletakkan pondasi dasarnya yakni laisses faire (Zainol dan Mahyudi 2020). 


\section{Kapitalisme Lanjut (Pasca 1914)}

Pada fase ini, kapitalisme mulai berkembang dan kuat yang ditandai oleh tiga momentum, yaitu:

a) Adanya kesadaran dari bangsa Asia dan Afrika terhadap penjajahan Eropa yang membuat bangsa Asia melakukan perlawanan.

b) Adanya perpindahan penguasaan aset dari Eropa ke Amerika.

c) Adanya revolusi Bolshevik Rusia yang meluluhlantakkan institusi fundamental kapitalisme yang berupa pemilikan secara individu atas penguasaan sarana produksi, struktur kelas sosial, bentuk pemerintahan dan kemapanan agama.

Kemudian ada tiga hal yang menjadi sifat dasar dari kapitalisme ini yang melandasi adanya penindasan sejak awal munculnya kapitalisme, yakni: eksploitasi, akumulasi, dan ekspansi (Zainol dan Mahyudi 2020).

Sistem ekonomi kapitalis mempunyai beberapa pilar, sebagai berikut:

- Private property atau hak milik swasta

- The Invisible Hand atau tangan-tangan tidak terlihat

- Individualisme ekonomi

- Free Market competation atau persaingan pasar bebas.

Selain itu, berikut akan dipaparkan beberapa kelebihan dan kekurangan dari sistem ekonomi kapitalisme (Tho'in 2015).

\begin{tabular}{lllr}
\hline \multicolumn{2}{c}{ Kelebihan } & \multicolumn{3}{c}{ Kekurangan } \\
\hline $\begin{array}{l}\text { Kapitalisme mendorong pertumbuhan } \\
\text { ekonomi dengan memfasilitasi kompetisi } \\
\text { pasar terbuka. }\end{array}$ & $\begin{array}{l}\text { Ekonomi } \\
\text { menimbulkan persaingan pasar yang } \\
\text { tidak sehat. }\end{array}$ & kapitalisme & dapat \\
\hline $\begin{array}{l}\text { Menyediakan individu kesempatan lebih } \\
\text { baik untuk meningkatkan pendapatan }\end{array}$ & $\begin{array}{l}\text { Mampu membuat ekonomi yang } \\
\text { berorientasi pada uang. Perusahaan akan }\end{array}$ \\
yang demikian akan memabntu & $\begin{array}{l}\text { melihat ekonomi dengan titik pandang } \\
\text { mencapai pertumbuhan ekonomi. }\end{array}$ & materealistik. & \\
\hline $\begin{array}{l}\text { Sistem ekonomi yang terdesentralisasi } \\
\text { dimana individu memiliki banyak pilihan }\end{array}$ & $\begin{array}{l}\text { Mampu menyebabkan distribusi } \\
\text { kekayaan yang tidak adil dengan } \\
\text { kalam bisnis. }\end{array}$ & $\begin{array}{l}\text { kekayaan yang hanya dimiliki oleh } \\
\text { segelintir orang saja. }\end{array}$ \\
& & & \\
\hline
\end{tabular}




\section{DAFTAR PUSTAKA}

Huda, Choirul. 2016. "Ekonomi Islam dan Kapitalisme ( Menurut Benih Kapitalisme dalam Ekonomi Islam )." Conomica VII(1): 27-49.

Parakkasi, Idris, dan Kamiruddin. 2018. "Analisis Harga Dan Mekanisme Pasar Dalam Perspektif Islam.” Laa Maisyir: Jurnal Ekonomi Islam : Jurnal Ekonomi Islam 5(1): 107-20.

Tho'in, Muhammad. 2015. “Konsep Ekonomi Islam Jalan Tengah (Kapitalis Sosialis).” Jurnal Ilmiah Ekonomi Islam 01(03): 118-33.

Zainol, Hasan., dan Mahyudi. 2020. “Analisis terhadap Pemikiran Ekonomi Kapitalisme Adam Smith.” Istidlal 4(1): 24-34. 